\title{
How Bark Beetle Attack Changes the Tensile and Compressive Strength of Spruce Wood (Picea abies (L.) H. Karst.)
}

\author{
Radim Löwe *(D), Miroslav Sedlecký, Adam Sikora, Anna Prokůpková, Roman Modlinger (), Karel Novotný \\ and Marek Turčáni ${ }^{1}$
}

Citation: Löwe, R.; Sedlecký, M.; Sikora, A.; Prokůpková, A.; Modlinger, R.; Novotný, K.; Turčáni, M. How Bark Beetle Attack Changes the Tensile and Compressive Strength of Spruce Wood (Picea abies (L.) H. Karst.). Forests 2022, 13, 87. https:// doi.org/10.3390/f13010087

Academic Editor: Simon Curling

Received: 10 November 2021

Accepted: 4 January 2022

Published: 8 January 2022

Publisher's Note: MDPI stays neutral with regard to jurisdictional claims in published maps and institutional affiliations.

Copyright: (C) 2022 by the authors. Licensee MDPI, Basel, Switzerland. This article is an open access article distributed under the terms and conditions of the Creative Commons Attribution (CC BY) license (https:// creativecommons.org/licenses/by/ $4.0 /)$.
Faculty of Forestry and Wood Sciences, Czech University of Life Sciences Prague, Kamýcká 129, 16500 Prague, Czech Republic; sedlecky@fld.czu.cz (M.S.); sikoraa@fld.czu.cz (A.S.); prokupkovaa@fld.czu.cz (A.P.); modlinger@fld.czu.cz (R.M.); novotnykarel@fld.czu.cz (K.N.); turcani@fld.czu.cz (M.T.)

* Correspondence: lowe@fld.czu.cz; Tel.: +420-224-383-756

\begin{abstract}
Since 2014, forestry in the Czech Republic has been significantly affected by a bark beetle outbreak. The volume of infested trees has exceeded processing capacity and dead standing spruce (Picea abies) remain in the forest stands, even for several years. What should be done with this bark beetle wood? Is it necessary to harvest it in order to preserve the basic mechanical and physical properties? Is it possible to store it under standard conditions, or what happens to it when it is "stored" upright in the forest? These are issues that interested forest owners when wood prices were falling to a minimum (i.e., in 2018-2019) but also today, when the prices of quality wood in Central European conditions are rising sharply. To answer these questions, we found out how some of the mechanical properties of wood change in dead, bark beetle-infested trees. Five groups of spruce wood were harvested. Each of these groups was left upright in the forest for a specified period of time after bark beetle infestation, and one group was classified as a reference group (uninfested trees). Subsequently, we discovered what changes occurred in tensile and compressive strength depending on the time left in the stand and the distance from the center of the trunk. When selecting samples, we eliminated differences between individual trees using a CT scanning technique, which allowed us to separate samples, especially with different widths of annual rings and other variations that were not caused by bark beetle. The results showed the effect of log age and radial position in the trunk on tensile and compressive strength. The values for tensile strength in 3-year infested trees decreased compared to uninfested trees by $14 \%$ (from $93.815 \mathrm{MPa}$ to $80.709 \mathrm{MPa}$ ); the values for compressive strength then decreased between the same samples by up to $25.6 \%$ (from $46.144 \mathrm{MPa}$ to $34.318 \mathrm{MPa}$ ). A significant decrease in values for compressive strength was observed in the edges of the trunks, with 44.332 MPa measured in uninfested trees and only 29.750 MPa in 3-year infested trees (a decrease of $32.9 \%$ ). The results suggest that the use of central timber from bark beetle-infested trees without the presence of moulds and fungi should not be problematic for construction purposes.
\end{abstract}

Keywords: Norway spruce; bark beetle outbreak; wood quality; wood properties; dead wood

\section{Introduction}

Bark beetle outbreaks are a central factor that lead to extensive changes in the structure, function, and composition of forest ecosystems [1,2]. In recent decades, bark beetle outbreaks have intensified globally, which also affects forestry economics and human well-being [3]. Forests and forestry in the Czech Republic have been facing a bark beetle outbreak of unprecedented magnitude since 2014. Hlásny et al. [3] maps in detail the reasons that led to this calamity. One of the reasons is that, for commercial reasons, Czech forestry grew high-quality, productive spruce stands on $55 \%$ of the forest area. Successive dry and warm years as a result of increasing climate change have made spruce stands growing outside their optimal distribution range highly threatened and attractive for bark 
beetle infestation. This situation quickly grew from a local problem in Central Moravia into a national outbreak, which significantly affected wood prices. The Czech Ministry of Agriculture relaxed conditions for processing trees infested with bark beetles, which had to be harvested under the original regulations, and thus several million $\mathrm{m}^{3}$ of dead spruces remained in forest stands [3,4]. Nevertheless, in 2020, 32.3 million $\mathrm{m}^{3}$ of spruce wood was harvested in Czechia [5]. Within Central Europe, the Czech wood market is not alone; sales problems associated with the bark beetle outbreak have been recorded throughout Central Europe, which has exacerbated this unfavourable situation [3,4]. Smaller forest owners were often forced to harvest all their spruce wood and sell it under unfavourable conditions. In some cases, their financial situation did not even allow them to harvest the infested spruces. Large producers, such as state forests, lacked the processing capacity, so these owners sought to harvest freshly infested spruces on the edges of outbreak areas as a matter of priority in order to at least partially slow down the outbreak. As early as 2018, spruces killed by bark beetle started appearing in forest stands, and in some cases have remained there until now. In 2018 and 2019, these dead trees were sold essentially at production costs as bark beetle wood, of which there was a huge surplus on the market at that time. However, the rise in wood prices, which was recorded in Central Europe at the beginning of 2021, and which is still ongoing, raises the question of whether these standing dead bark beetle trees could not be used for purposes better than, for example, wood chip production. Profit from the sale of wood is the primary source of income in forestry. Therefore, it is necessary to not only determine its volume as accurately as possible [6], but also to know its quality [7]. From a political and economic point of view, such a strategy would also make it possible to obtain funding for afforestation of outbreak areas and subsequent management of these stands.

Spruce bark beetles colonize stressed and dying trees when their populations are low. However, if their population is high, then they also massively attack large numbers of healthy trees [4]. Bark beetle-infested trees may subsequently show a different wood quality from healthy trees. The wood quality can thus be different, especially with regard to its structure, physical properties, and mechanical properties. Several studies have already addressed this issue [8-12]; however, the scientific literature has not yet answered all the questions related to the properties of wood from bark beetle-infested trees. Current scientific findings have been summarized in a review article by Hýsek et al. [7]. If we focus on the mechanical properties of spruce wood infested with bark beetles, their change was monitored mainly in the longer term (several years) and was caused mainly indirectly (by fungal activity) [8]. Jelonek et al. [8] state that spruce stands that are dead as a result of bark beetle infestation and, secondarily, ophiostomatoid fungi, pose a risk to people after 3 or more years. The authors also recommended that wood from these spruces be used in industry for construction purposes no later than the first or second year after bark beetle infestation. However, in the case of wood thus used, it is always necessary to keep in mind that it most likely contains fungal spores and hyphae [12], which can activate in the wooden structure at any time and start growing if they have suitable humidity conditions. However, it is clear that the above conclusions and recommendations of the authors cannot be generally valid because the time period when the wood properties of dead bark beetle-infested trees do not change compared to normal wood tree properties depends on the tree species, specific site factors, and season [7].

In this study, we accordingly focused on the description of the mechanical properties of bark beetle-infested spruces under specific local climatic conditions in a selected area of the Czech Republic, which was massively affected by the bark beetle outbreak 4 years ago. It is the Czech Republic that has recently become the epicentre of Europe's spruce bark beetle outbreak [3]. The aim of this study was to determine how the selected mechanical properties of wood (tensile and compressive strength) differ between spruces dead after bark beetle infestation and left in the forest stand upright for different lengths of time. This information is essential for foresters managing the affected forests when planning the processing or non-processing of infested trees, considering the possibilities of using 
this wood, and formulating the subsequent business strategy. With unchanged properties, more valuable assortments can be produced from infested trees, which will bring higher economic value to forest owners affected by bark beetle outbreaks.

\section{Materials and Methods}

\subsection{Materials}

In a forest stand near Huntírov (Děčínsko, Ustí nad Labem Region, Czechia: 50.7930 N; 14.2897 E), four groups of standing spruces (Picea abies) that had died after infestation by the European spruce bark beetle (Ips typographus) were selected. Each group formed a continuous part of the stand, which was infested with the bark beetle and had died within the same period of time. Individual groups of trees were left in the stand for $1 / 2$ year, 1 year, 2 years, and 3 years. From each group of equally old dry trees, five trees were randomly selected, and five living trees were randomly selected in the same stand. A rhizome piece about 1 metre above the ground with a length of $1.4 \mathrm{~m}$ was cut from selected trees. The diameter of the trees was about $40 \mathrm{~cm}$. Out of the selected 25 trunks, there was a further reduction so that one trunk remained from each group that was most similar in density and annual rings (Age of Log; Table 1). To avoid skewing of the results, the trunks and subsequent samples were handled so that differences in their annual ring width, age, proportion of earlywood and latewood, etc., were as minimal as possible. A CT scanning device was used to select the samples, thus making it possible to reduce the above-mentioned differences to a minimum. A Siemens medical CT scanning device, which is primarily intended for medicine, was used. Cutouts of the specified length were scanned. The samples themselves were subsequently prepared according to standards ČSN 490110 and 490113 for measuring compressive and tensile strength [13,14]. Sample production took place immediately after felling. The prepared samples were placed in an air-conditioned chamber to ensure constant conditions (65\% relative humidity and $20{ }^{\circ} \mathrm{C}$ ). The descriptions and sampling are given in Table 1 and shown in Figure 1.

Table 1. Marking of Samples.

\begin{tabular}{ccc}
\hline Age of Log (Years) & Log Number & Distance from Center \\
\hline $0 ; 0.5 ; 1 ; 2 ; 3$ & $1 ; 2 ; 3 ; 4 ; 5$ & $1 ; 2 ; 3 ; 4 ; 5$ \\
\hline $\begin{array}{l}\text { Key: Age of Log—0—living tree; } 0.5 \text { —infested in summer 2020;1—infested in spring 2020;2—infested in spring } \\
\text { 2019;3—infested in spring 2018. }\end{array}$
\end{tabular}

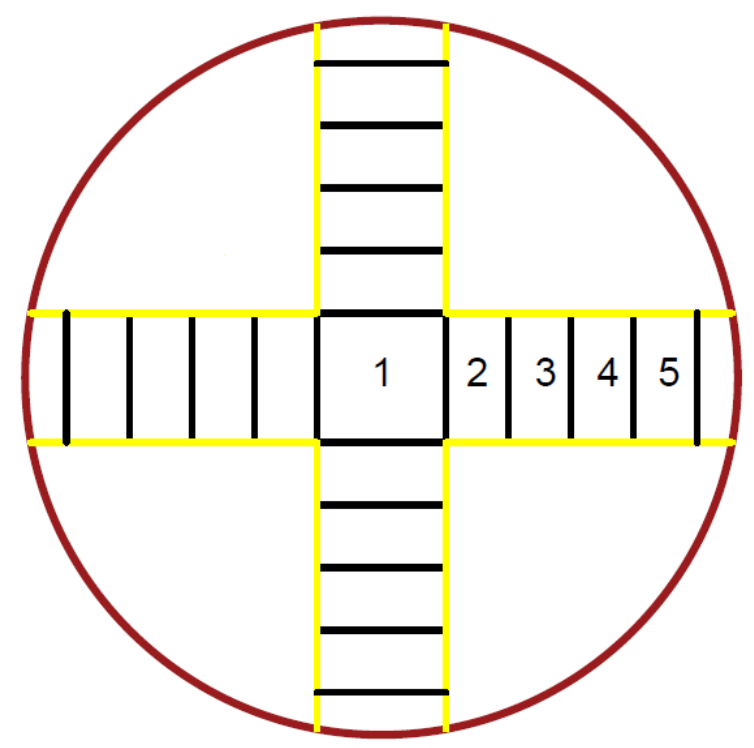

Figure 1. Place of sampling-Distance from center. 
Figure 2 shows the differences in a living tree compared with infested trees. The living tree is visibly without circumferential cracks and shows a clear distinction between heartwood and sapwood. In infested trees that had been left standing in the forest, cracks are visible; the older the tree, the more and larger the cracks. Furthermore, on the infested trees, we observed a different colour at the border of heartwood and sapwood. Different colours indicate different densities and associated humidity in the area [15]. CT scanning helped us to eliminate obvious differences between samples so that the results were not skewed. CT substrates were evaluated optically from CT outputs to exclude parts of the trunks with detectable deviations and wood disturbance, as this selection would have been performed at a sawmill. The influence of the width of annual rings, the ratio between earlywood and latewood, wood density, the occurrence of rot, spores and hyphae of fungi, and similar factors have a major impact on the resulting mechanical properties of the wood [8,12,16-19].
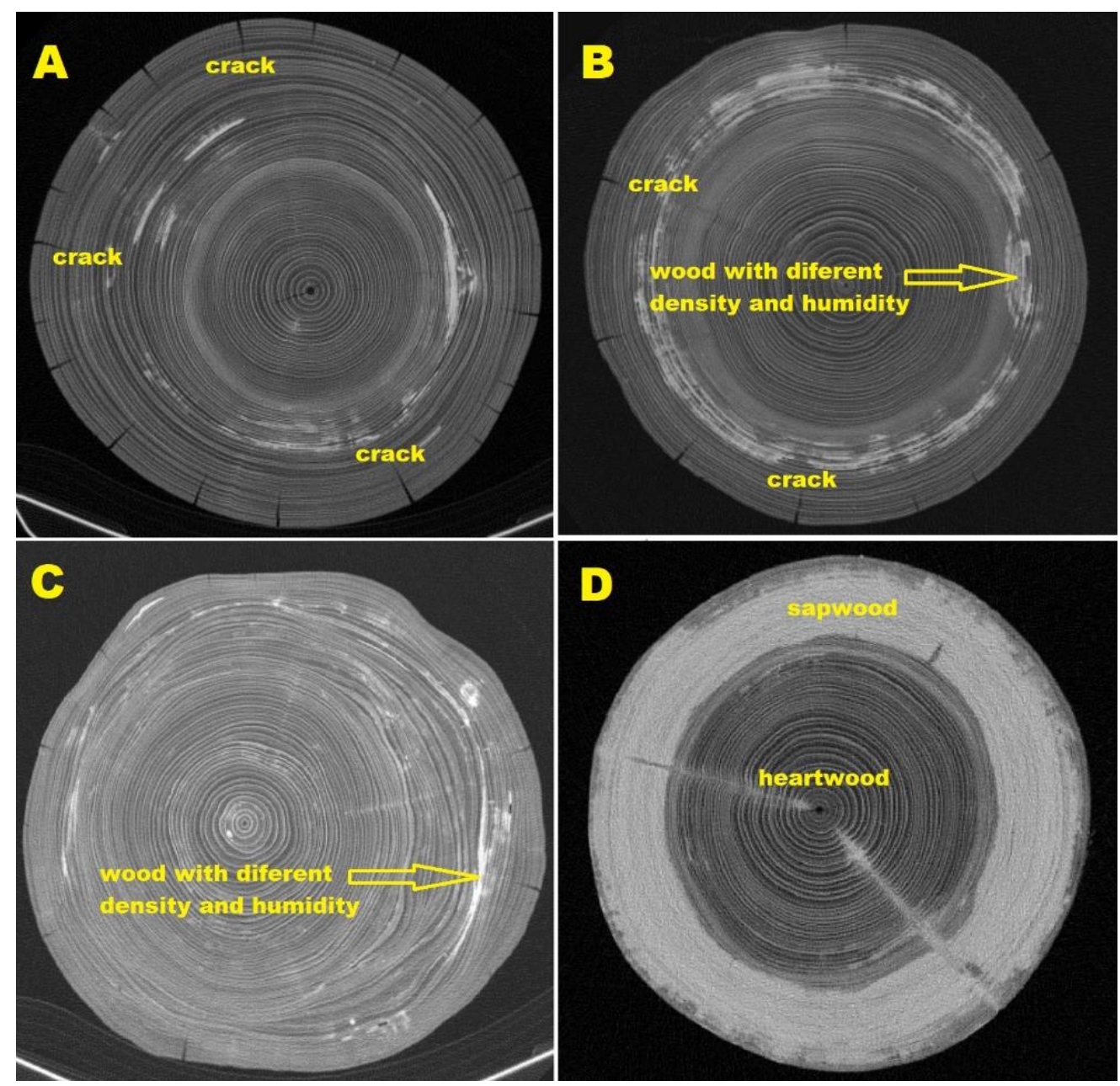

Figure 2. Spruce wood scanned by CT: (A) 3-infested in spring 2018; (B) 2-infested in spring 2019; (C) 1-infested in spring 2020; (D) 0-living tree.

\subsection{Methods}

\subsubsection{Determining Selected Characteristics}

Tensile and compressive tests were performed according to predetermined conditions. The tests were performed on a universal testing machine (FPZ 100, TIRA, Schalkau, Germany), according to $[13,14]$. The test samples for the pressure test had the shape of a rectangular prism with a cross-section of $20 \mathrm{~mm} \times 20 \mathrm{~mm}$ and a height of $30 \mathrm{~mm}$. Tensile test specimens were made of blanks with a cross-section of $20 \mathrm{~mm} \times 20 \mathrm{~mm}$ and a length of $350 \mathrm{~mm}$; each blank was machined according to Figure 3 . To adhere to the duration limit 
for the individual tests ( $60 \pm 30 \mathrm{~s}$ for the compressive test and $105 \pm 15 \mathrm{~s}$ for the tensile test), the top support feed rate was set accordingly. Maximal force at breaking point was used for calculation of compressive and tensile strength. The deflections of loaded test samples were measured using an ALMEMO 2690-8 datalogger (Ahlborn GmbH, Braunschweig, Germany).
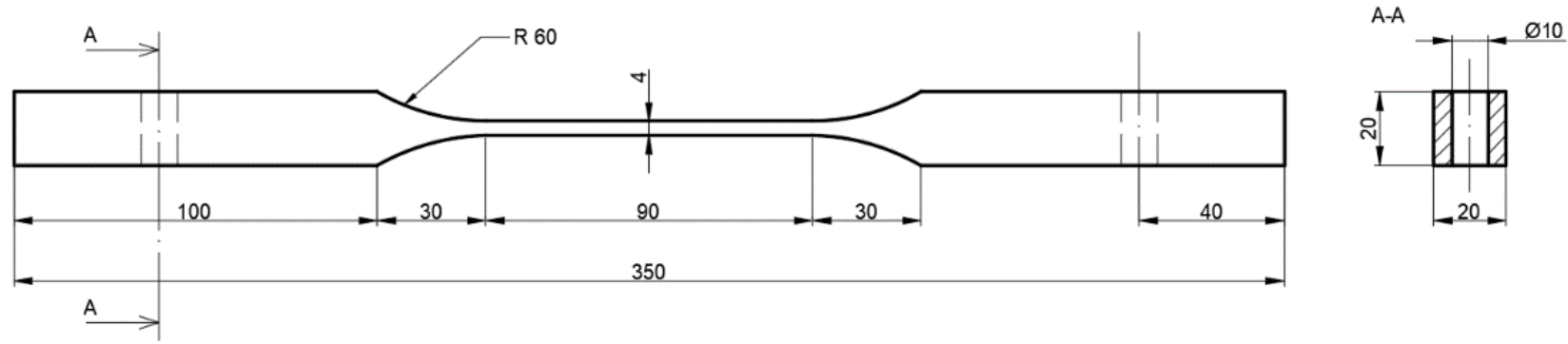

Figure 3. Shape and dimensions of test samples for tensile test according to [14].

\subsubsection{Evaluation and Calculation of Tensile and Compressive Strength}

The tensile strength of the wood along the fibres was calculated according to the standard [14] using Equation (1).

$$
\sigma_{t \max }=\frac{F_{\max }}{a b}
$$

where $\sigma_{t}$ max is the maximal strength in tension along wood fibre (MPa), $a$ is width of the working part of the test sample $(\mathrm{mm})$, and $b$ is thickness of the working part of the test sample (mm).

The compressive strength of the wood along the fibres was calculated according to the standard [13] using Equation (2).

$$
\sigma_{c \max }=\frac{F_{\max }}{a b}
$$

where $\sigma_{c \text { max }}$ is the maximal strength in compression along wood fibre (MPa), $a$ is the width of the test sample (mm), and $b$ is the thickness of the test sample $(\mathrm{mm})$.

Before evaluating the data by analysis of variance (ANOVA), the normality of the data was verified by the Shapiro-Wilk test on the residues of the linear model. Due to the confirmation of the normality of the data distribution (Gaussian distribution), the Bartlett test was used to determine the agreement of the variances; the agreement of the variances was not confirmed, and therefore, a modified ANOVA for unequal variances was used [20]. Duncan's test was also used for deeper analysis to compare all sets of test specimens. The test could be used because a statistically significant difference in ANOVA evaluation was confirmed. The results were evaluated using a 95\% confidence interval. STATISTICA 13 software (TIBCO Software Inc., Palo Alto, CA, USA) was used for statistical data evaluation.

\section{Results and Discussion}

The mechanical properties of wood are always dependent on many factors [21], one of the most important being density. Table 2 shows that variability between densities between groups in terms of age of log and position in the trunk is not very significant. The influence of density on given mechanical properties is reported in research [22]: the compressive strength increases with increasing density. Additionally, based on research [23], we can say that we can largely predict the strength characteristics of wood according to its density. Density was measured on all samples and then averaged over each group. 
Table 2. Average density values for individual groups according to age of log and position.

\begin{tabular}{cccccc}
\hline Age of Log & $\begin{array}{c}\text { Density } \\
\left(\mathbf{k g} \cdot \mathbf{m}^{-\mathbf{3}} \mathbf{)}\right.\end{array}$ & $\begin{array}{c}\text { Standard } \\
\text { Deviation }\end{array}$ & Position & $\begin{array}{c}\text { Density } \\
\mathbf{( k g} \cdot \mathbf{m}^{-\mathbf{3}} \mathbf{)}\end{array}$ & $\begin{array}{c}\text { Standard } \\
\text { Deviation }\end{array}$ \\
\hline 0 & 486.15 & 25.18 & 1 & 471.64 & 22.57 \\
0.5 & 472.58 & 19.39 & 2 & 473.92 & 27.47 \\
1 & 465.32 & 24.84 & 3 & 483.38 & 25.31 \\
2 & 447.27 & 22.78 & 4 & 466.37 & 20.18 \\
3 & 452.02 & 20.63 & 5 & 456.29 & 25.32 \\
\hline
\end{tabular}

Statistical evaluation using ANOVA and Duncan tests (Table 3; Figure 4) shows a clear course of change in the monitored mechanical properties of infested wood. The highest values were measured for an uninfected tree that was selected as a reference value (0). The values for the summer 2020 sample (0.5) did not show statistically significant differences from the reference value. For the other "older" trees, a statistically significant difference from the reference value was confirmed, and the tensile strength values were lower. It showed that the longer the trunk is left standing dead in the forest, the lower the value for wood density. The decrease in values from reference value for trunks stored since spring 2018 was $14 \%$. This decrease could be partly due to a decrease in density between the mentioned samples [24], but also to the climatic stress that caused the trees to die before they were cut. The dead trees were climate-dried, and this effect of uncontrolled drying can cause cracks, as also confirmed by research on the effects of climate on the rate of wood mass drying $[9,25]$.

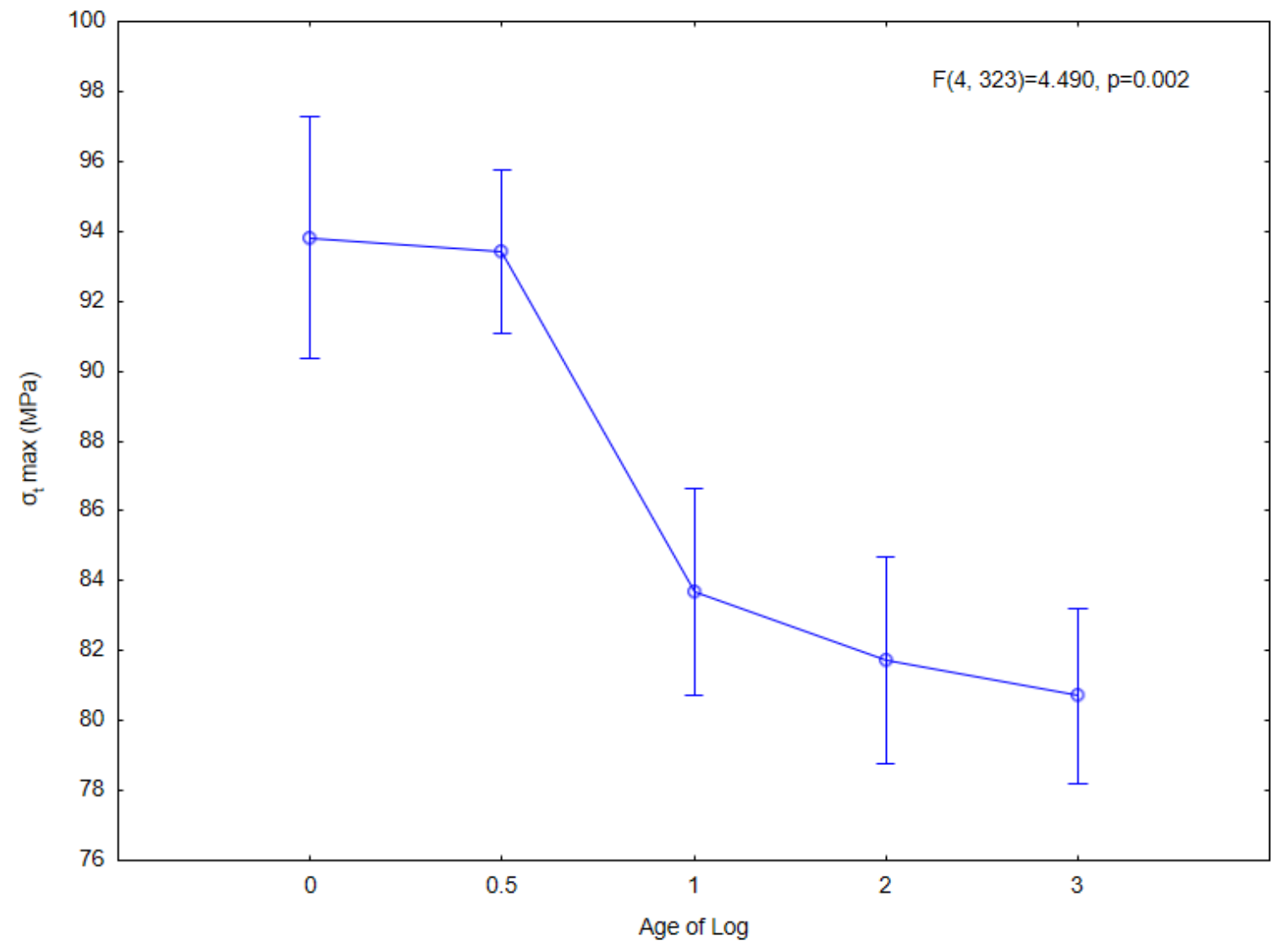

Figure 4. Statistical evaluation of the effect of log age on tensile strength using ANOVA. 
Table 3. Statistical evaluation of the effect of log age (AoL) on tensile strength using Duncan's test.

\begin{tabular}{cccccccc}
\hline \multicolumn{2}{c}{$\sigma_{\mathbf{t}}$ Max (MPa) } & (1) $\mathbf{9 3 . 8 1 5}$ & (2) $\mathbf{9 3 . 4 3 7}$ & (3) 83.687 & (4) 81.749 & (5) 80.709 & $\mathbf{N}$ \\
\hline Number & $\mathbf{( A o L )}$ & & & & & & \\
\hline 1 & 0 & - & 0.920 & 0.009 & 0.002 & 0.001 & 67 \\
2 & 0.5 & 0.920 & - & 0.009 & 0.002 & 0.001 & 66 \\
3 & 1 & 0.009 & 0.009 & - & 0.604 & 0.456 & 68 \\
4 & 2 & 0.002 & 0.002 & 0.604 & - & 0.781 & 70 \\
5 & 3 & 0.001 & 0.001 & 0.456 & 0.781 & - & 77 \\
\hline
\end{tabular}

$\sigma_{t}$ max-tensile strength of the wood along the fibres.

When evaluating the effect of distance from the center of the trunk on tensile strength, which is shown in Table 4 and Figure 5, no statistically significant difference was found in areas 1-4. A very significant statistical difference was only shown in area 5, which was furthest from the center of the trunk. In this outer wood layer, the tensile strength values decreased by $22.9 \%$. This decrease was mainly due to cracks caused by drying and microcracks in the circumferential sections. This phenomenon is caused by the uncontrolled drying of a dead tree. The effect of drying is very important for the quality of timber and affects its mechanical properties as well [26].

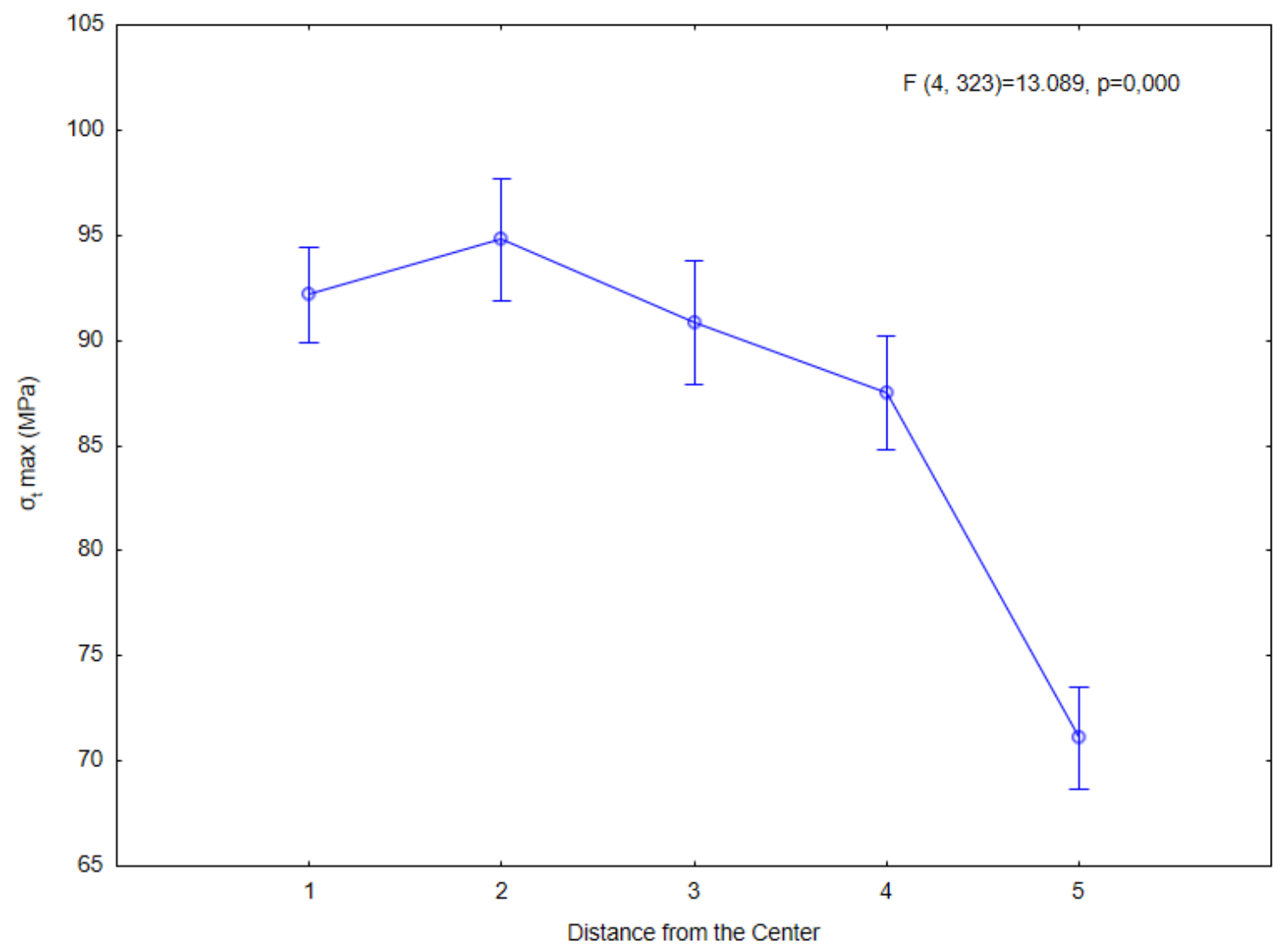

Figure 5. Statistical evaluation of the effect of distance from center on tensile strength using ANOVA. 
Table 4. Statistical evaluation of the effect of distance from center (DfC) on tensile strength using Duncan's test.

\begin{tabular}{cccccccc}
\hline \multicolumn{2}{c}{$\sigma_{\mathbf{t}}$ Max (MPa) } & (1) $\mathbf{9 2 . 1 7 7}$ & (2) $\mathbf{9 4 . 7 9 1}$ & (3) $\mathbf{9 0 . 8 4 0}$ & (4) 87.535 & (5) 71.096 & $\mathbf{N}$ \\
\hline Number & DfC & & & & & & \\
\hline 1 & 1 & - & 0.492 & 0.725 & 0.253 & 0.000 & 50 \\
2 & 2 & 0.492 & - & 0.331 & 0.082 & 0.000 & 57 \\
3 & 3 & 0.725 & 0.331 & - & 0.385 & 0.000 & 82 \\
4 & 4 & 0.253 & 0.082 & 0.385 & - & 0.000 & - \\
5 & 5 & 0.000 & 0.000 & 0.000 & 0.000 & 79 \\
\hline
\end{tabular}

$\sigma_{t}$ max-tensile strength of the wood along the fibres.

The influence of the interaction of both factors on tensile strength is shown in Figure 6 as well as in Table 5. The tensile strength in the outer layer of the trunk is very low and undergoes almost no change with the age of the trunk. In layers No. 4 and 3, there was a decrease in the tensile strength at the age of about 1 year after bark beetle infestation. For the middle wood layers (No. 2 and 1), the reduction in tensile strength was only significant after 2 years.

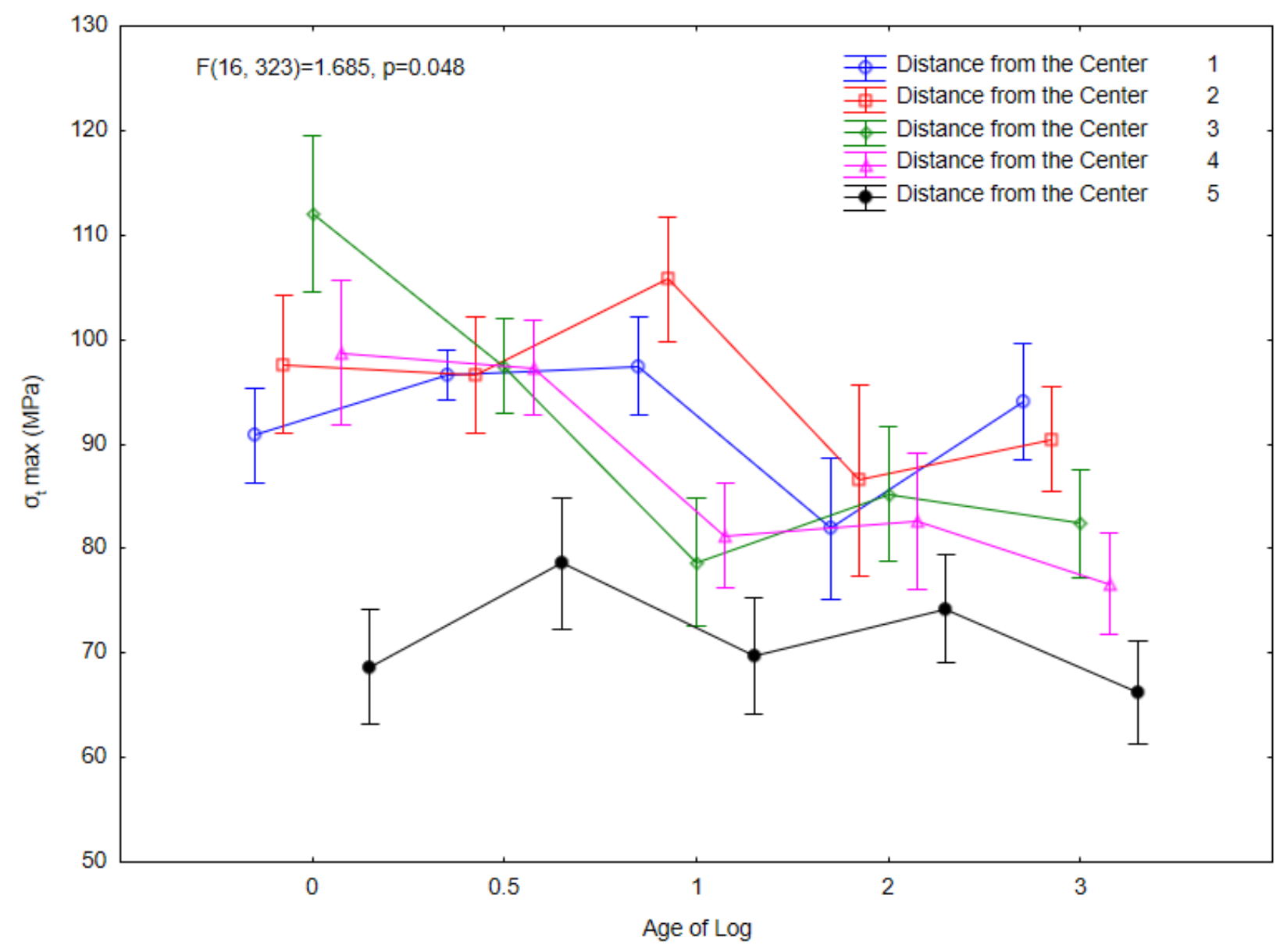

Figure 6. Statistical evaluation of the effect of age of log and distance from center on tensile strength using ANOVA. 
Table 5. ANOVA spreadsheet-Age of log and distance from center-influence on tensile strength.

\begin{tabular}{|c|c|c|c|c|c|c|c|}
\hline No. & $\begin{array}{l}\text { Age of Log } \\
\text { (Years) }\end{array}$ & $\begin{array}{c}\text { Distance } \\
\text { from Center }\end{array}$ & $\begin{array}{c}\sigma_{t} \text { Max } \\
\text { (Mpa) Mean }\end{array}$ & $\begin{array}{c}\sigma_{\mathrm{t}} \text { Max (Mpa) } \\
\text { Std. Err. }\end{array}$ & $\begin{array}{c}\sigma_{\mathrm{t}} \text { Max (Mpa) } \\
\text { - Std. Err. }\end{array}$ & $\begin{array}{c}\sigma_{\mathrm{t}} \text { Max (Mpa) } \\
+ \text { +Std. Err. }\end{array}$ & $\mathbf{N}$ \\
\hline 1 & 0 & 1 & 90.809 & 4.511 & 86.298 & 95.320 & 10 \\
\hline 2 & 0 & 2 & 97.609 & 6.565 & 91.044 & 104.174 & 10 \\
\hline 3 & 0 & 3 & 112.020 & 7.490 & 104.530 & 119.510 & 16 \\
\hline 4 & 0 & 4 & 98.723 & 6.955 & 91.767 & 105.678 & 16 \\
\hline 5 & 0 & 5 & 68.635 & 5.491 & 63.144 & 74.126 & 15 \\
\hline 6 & 0.5 & 1 & 96.658 & 2.362 & 94.296 & 99.020 & 10 \\
\hline 7 & 0.5 & 2 & 96.558 & 5.590 & 90.968 & 102.148 & 10 \\
\hline 8 & 0.5 & 3 & 97.417 & 4.531 & 92.886 & 101.948 & 16 \\
\hline 9 & 0.5 & 4 & 97.320 & 4.495 & 92.825 & 101.815 & 17 \\
\hline 10 & 0.5 & 5 & 78.584 & 6.242 & 72.342 & 84.826 & 13 \\
\hline 11 & 1 & 1 & 97.473 & 4.634 & 92.839 & 102.107 & 10 \\
\hline 12 & 1 & 2 & 105.761 & 5.953 & 99.808 & 111.714 & 10 \\
\hline 13 & 1 & 3 & 78.690 & 6.148 & 72.541 & 84.838 & 18 \\
\hline 14 & 1 & 4 & 81.224 & 5.003 & 76.221 & 86.227 & 13 \\
\hline 15 & 1 & 5 & 69.768 & 5.582 & 64.186 & 75.350 & 17 \\
\hline 16 & 2 & 1 & 81.907 & 6.687 & 75.220 & 88.594 & 10 \\
\hline 17 & 2 & 2 & 86.555 & 9.158 & 77.397 & 95.713 & 10 \\
\hline 18 & 2 & 3 & 85.209 & 6.440 & 78.769 & 91.650 & 16 \\
\hline 19 & 2 & 4 & 82.588 & 6.558 & 76.030 & 89.145 & 18 \\
\hline 20 & 2 & 5 & 74.241 & 5.139 & 69.102 & 79.380 & 16 \\
\hline 21 & 3 & 1 & 94.037 & 5.548 & 88.489 & 99.585 & 10 \\
\hline 22 & 3 & 2 & 90.485 & 5.004 & 85.481 & 95.489 & 17 \\
\hline 23 & 3 & 3 & 82.384 & 5.181 & 77.202 & 87.565 & 16 \\
\hline 24 & 3 & 4 & 76.643 & 4.902 & 71.741 & 81.545 & 16 \\
\hline 25 & 3 & 5 & 66.199 & 4.910 & 61.289 & 71.109 & 18 \\
\hline
\end{tabular}

$\sigma_{t}$ max-tensile strength of the wood along the fibres.

When evaluating the effect of the age of the log on compressive strength, a statistically significant difference showed in all categories (Table 6). The highest values were measured for the reference sample and the lowest for the oldest one. The highest decrease compared to the reference group was up to $25.6 \%$. This decrease was caused by several factors such as density $[23,27]$ and weathering $[27,28]$, as well as uncontrolled drying. This stress can be associated not only with the formation of cracks, but under certain climatic conditions also the infestation of wood with fungi and the associated possible occurrence of rot $[8,9,25,28]$ (Figure 2). The influence of internal defects on compressive strength has also been proven by research [27]. Figure 7 shows a clear difference between trees in age groups 0 and 3; the others did not show such a clear trend of change in compressive strength. The compressive strength values for categories $0.5,1$, and 2 were around $40 \mathrm{MPa}$, which was about $6 \mathrm{MPa}$ from the minimum and maximum.

Table 6. Statistical evaluation of the effect of log age (AoL) on compressive strength using Duncan's test.

\begin{tabular}{cccccccc}
\hline \multicolumn{2}{c}{$\boldsymbol{\sigma}_{\mathbf{c}}$ Max (MPa) } & (1) $\mathbf{4 6 . 1 4 4}$ & (2) $\mathbf{4 1 . 3 5 3}$ & (3) 37.409 & (4) $\mathbf{3 8 . 4 6 2}$ & (5) $\mathbf{3 4 . 3 1 8}$ & $\mathbf{N}$ \\
\hline Number & AoL & & & & & & \\
\hline 1 & 0 & & 0.000 & 0.000 & 0.000 & 0.000 & 203 \\
2 & 1 & 0.000 & & 0.000 & 0.000 & 0.000 & 192 \\
3 & 2 & 0.000 & 0.000 & & 0.042 & 0.000 & 205 \\
4 & 3 & 0.000 & 0.000 & 0.042 & & 0.000 & 235 \\
5 & 4 & 0.000 & 0.000 & 0.000 & 0.000 & & \\
\hline
\end{tabular}




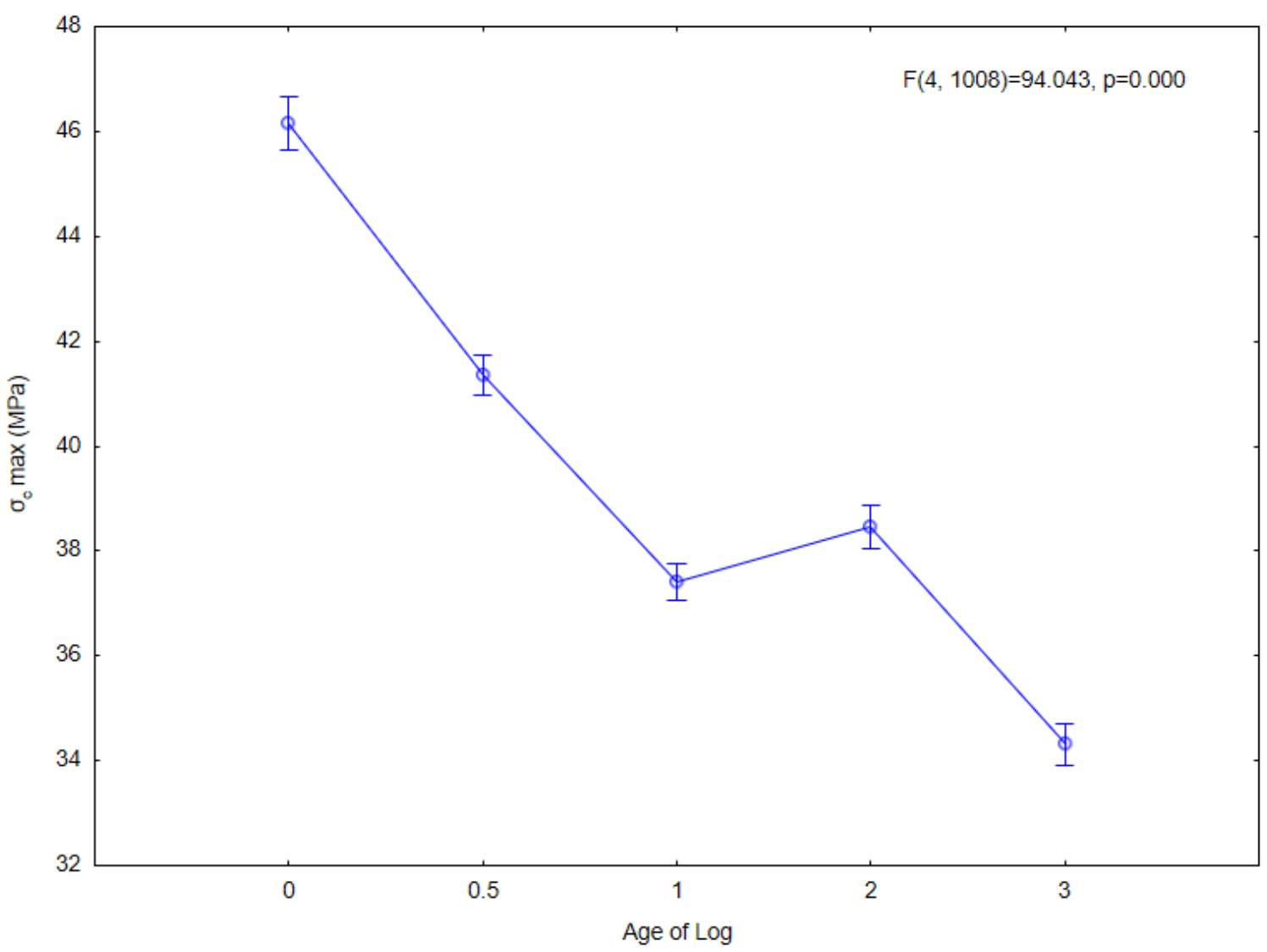

Figure 7. Statistical evaluation of the effect of log age on compressive strength using ANOVA.

Namely sections nearer the outer area showed a significant decrease in compressive strength (Table 7; Figure 8). In other sections, a statistically significant difference was demonstrated in some cases, but the values did not have an increased coefficient of variation; in the case of anatomical differences in wood, these sections were relatively balanced. The position of wood in the trunk with respect to its cross section is an important factor influencing wood properties [28,29]. The importance of this factor is, therefore, amplified in the case of bark beetle infestation.

Table 7. Statistical evaluation of the effect of distance from center (DfC) on compressive strength using Duncan's test.

\begin{tabular}{cccccccc}
\hline \multicolumn{2}{c}{$\sigma_{\mathrm{c}}$ Max (MPa) } & (1) $\mathbf{3 9 . 9 0 9}$ & (2) 41.547 & (3) 41.395 & (4) 39.897 & $\mathbf{( 5 )} 35.770$ & $\mathbf{N}$ \\
\hline Number & DfC & & & & & & \\
\hline 1 & 1 & & 0.009 & 0.013 & 0.984 & 0.000 & 0.000 \\
2 & 2 & 0.009 & & 0.801 & 0.010 & 0.000 & 243 \\
3 & 3 & 0.013 & 0.801 & & 0.017 & 0.000 & 296 \\
4 & 4 & 0.984 & 0.010 & 0.017 & & 0.000 & \\
5 & 5 & 0.000 & 0.000 & 0.000 & 281 \\
\hline
\end{tabular}




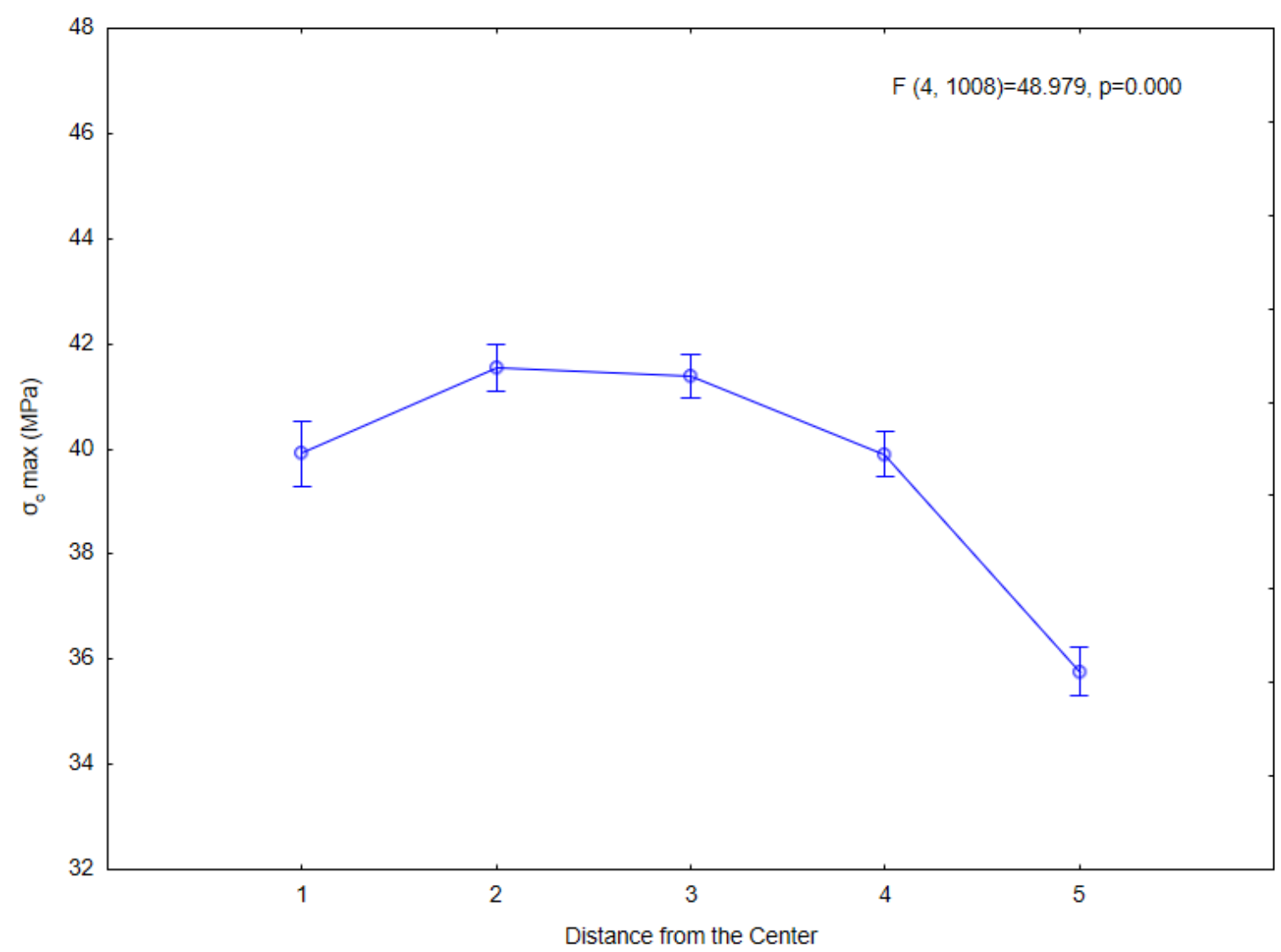

Figure 8. Statistical evaluation of the effect of distance from center on compressive strength using ANOVA.

When evaluating the statistical significance of the interaction of the time factor and the distance from the center of the trunk to compressive strength, a decrease in values with increasing age of the trunk was also evident (Table 8, Figure 9). However, for samples originating from individual distances from the center of the trunk, there was a statistically significantly different direction in the trend of this decrease. Samples originating from the center of the trunk (No. 1 and 2) exhibited a less downward trend, and, conversely, samples originating from the outer part of the trunk showed a very steep decrease in values. Due to the influence of radial position on mechanical properties, a number of studies have addressed it and drawn clear conclusions. With increases in cambial age, the density of early wood decreases, while latewood grows at first and does not change significantly. Regarding some mechanical properties (tensile strength and modulus of elasticity), there was an increase. The effect of density was then based primarily on changes in the width of the annual ring and the proportion of early- and latewood [30-32].

Table 8. ANOVA spreadsheet-Age of log and distance from center-influence on compressive strength.

\begin{tabular}{|c|c|c|c|c|c|c|c|}
\hline No. & $\begin{array}{l}\text { Age of Log } \\
\text { (Years) }\end{array}$ & $\begin{array}{c}\text { Distance } \\
\text { from Center }\end{array}$ & $\begin{array}{c}\sigma_{\mathrm{c}} \text { Max } \\
(\mathrm{MPa}) \text { Mean }\end{array}$ & $\begin{array}{c}\sigma_{\mathrm{c}} \operatorname{Max}(\mathrm{MPa}) \\
\text { Std. Err. }\end{array}$ & $\begin{array}{c}\sigma_{\mathrm{c}} \operatorname{Max}(\mathrm{MPa}) \\
- \text { Std. Err. }\end{array}$ & $\begin{array}{c}\sigma_{\mathrm{c}} \operatorname{Max}(\mathrm{MPa}) \\
+ \text { +Std. Err. }\end{array}$ & $\mathbf{N}$ \\
\hline 1 & 0 & 1 & 44.934 & 0.654 & 44.280 & 45.588 & 11 \\
\hline 2 & 0 & 2 & 45.523 & 0.885 & 44.638 & 46.408 & 32 \\
\hline 3 & 0 & 3 & 50.283 & 0.715 & 49.568 & 50.997 & 38 \\
\hline 4 & 0 & 4 & 45.803 & 0.895 & 44.908 & 46.698 & 66 \\
\hline 5 & 0 & 5 & 44.332 & 1.246 & 43.086 & 45.578 & 56 \\
\hline
\end{tabular}


Table 8. Cont.

\begin{tabular}{|c|c|c|c|c|c|c|c|}
\hline No. & $\begin{array}{l}\text { Age of Log } \\
\text { (Years) }\end{array}$ & $\begin{array}{c}\text { Distance } \\
\text { from Center }\end{array}$ & $\begin{array}{c}\sigma_{\mathrm{c}} \text { Max } \\
(\mathrm{MPa}) \text { Mean }\end{array}$ & $\begin{array}{c}\sigma_{\mathrm{c}} \operatorname{Max}(\mathrm{MPa}) \\
\text { Std. Err. }\end{array}$ & $\begin{array}{c}\sigma_{\mathrm{c}} \operatorname{Max}(\mathrm{MPa}) \\
- \text { Std. Err. }\end{array}$ & $\begin{array}{c}\sigma_{\mathrm{c}} \operatorname{Max}(\mathrm{MPa}) \\
+ \text { Std. Err. }\end{array}$ & $\mathbf{N}$ \\
\hline 6 & 0.5 & 1 & 39.588 & 1.789 & 37.800 & 41.377 & 10 \\
\hline 7 & 0.5 & 2 & 41.245 & 0.676 & 40.569 & 41.921 & 19 \\
\hline 8 & 0.5 & 3 & 43.043 & 0.600 & 42.443 & 43.643 & 48 \\
\hline 9 & 0.5 & 4 & 43.565 & 0.696 & 42.869 & 44.261 & 67 \\
\hline 10 & 0.5 & 5 & 36.987 & 0.648 & 36.339 & 37.635 & 48 \\
\hline 11 & 1 & 1 & 42.472 & 1.340 & 41.133 & 43.812 & 10 \\
\hline 12 & 1 & 2 & 39.319 & 0.771 & 38.548 & 40.090 & 27 \\
\hline 13 & 1 & 3 & 37.985 & 0.578 & 37.408 & 38.563 & 57 \\
\hline 14 & 1 & 4 & 37.672 & 0.598 & 37.074 & 38.269 & 55 \\
\hline 15 & 1 & 5 & 34.740 & 0.675 & 34.065 & 35.415 & 56 \\
\hline 16 & 2 & 1 & 35.600 & 1.174 & 34.426 & 36.774 & 10 \\
\hline 17 & 2 & 2 & 42.981 & 0.915 & 42.066 & 43.895 & 30 \\
\hline 18 & 2 & 3 & 40.828 & 0.667 & 40.161 & 41.495 & 52 \\
\hline 19 & 2 & 4 & 38.655 & 0.690 & 37.964 & 39.345 & 50 \\
\hline 20 & 2 & 5 & 34.185 & 0.623 & 33.561 & 34.808 & 56 \\
\hline 21 & 3 & 1 & 38.673 & 0.909 & 37.764 & 39.582 & 28 \\
\hline 22 & 3 & 2 & 38.564 & 0.810 & 37.754 & 39.374 & 35 \\
\hline 23 & 3 & 3 & 37.459 & 0.889 & 36.569 & 38.348 & 49 \\
\hline 24 & 3 & 4 & 32.121 & 0.569 & 31.552 & 32.690 & 58 \\
\hline 25 & 3 & 5 & 29.750 & 0.460 & 29.289 & 30.210 & 65 \\
\hline
\end{tabular}

$\sigma_{\mathrm{c}}$ max-compressive strength of wood along the fibres.

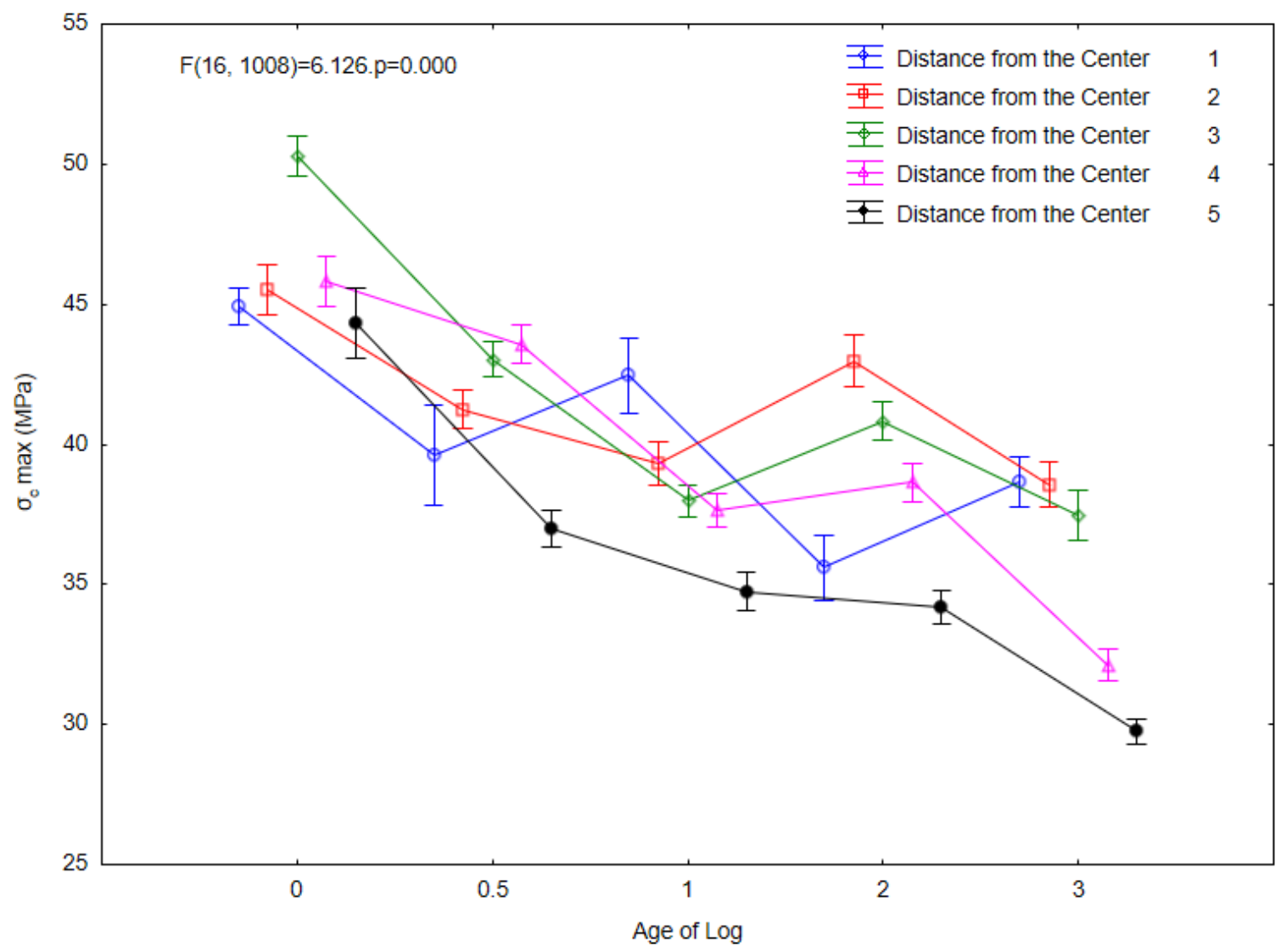

Figure 9. Statistical evaluation of the effect of age of log and distance from center on tensile strength using ANOVA. 


\section{Conclusions}

Based on the results obtained, it is possible to say that the longer the infested tree is left standing in the forest, the more the compressive and tensile strength are negatively affected. Research has shown statistically significant differences in the effect of age of log on compressive and tensile strength. It was clear that the 3-year-old tree had the lowest values, and conversely, the reference tree (not infested by bark beetle) had the highest values.

The distance from center of the trunk had a statistically significant effect on both the compressive and tensile strength only in the case of the furthest section from the center of the trunk compared to the other sections. This was mostly caused by cracks (Figure 2), which were mainly in the circumferential sections.

The decrease in tensile strength had an abrupt character. In the outer layers, it occurred 1 year after bark beetle infestation, while the middle part was significantly affected after 2 years. Changes in compressive strength properties were gradual, and they were faster near the trunk surface and slower at the center of the trunk.

Looking at the overall results, we can state that compressive and tensile strength were affected both by the age of storing and distance from the center of the trunk, as well as by the formation and density of cracks. This research suggests that the use of heartwood timber without the presence of moulds and fungi should not be a problem. While maintaining the required density and quality, this timber can also be used as a building material.

Author Contributions: Conceptualization, R.L., M.S., A.S. and M.T.; methodology, R.L., M.S., A.S. and M.T.; validation, R.L., M.S., A.S. and R.M.; formal analysis, R.L., M.S., A.S. and R.M.; investigation, R.L., A.P., M.S. and A.S.; resources, R.L., M.S., A.S., A.P. and K.N.; data curation, R.L., A.P., M.S. and A.S.; writing—original draft preparation, R.L., M.S., A.S., A.P., R.M., K.N. and M.T.; writing—review and editing, R.L., M.S., A.S., A.P., R.M and M.T.; visualization, R.L., M.S. and A.S.; supervision, M.T.; project administration, R.L. and M.T.; funding acquisition, M.T. All authors have read and agreed to the published version of the manuscript.

Funding: This research was funded by Národní Agentura pro Zemědělský Výzkum under project no. QK1920435:The improvement and support of communication, survey and management of outbreak and disaster situations as a tool for optimisation of state administration in the forestry sector, and by OP RDE under the project EXTEMIT-K, no. CZ.02.1.01/0.0/0.0/15_003/0000433.

Informed Consent Statement: Not applicable.

Data Availability Statement: Data are contained within the article.

Conflicts of Interest: The authors declare no conflict of interest.

\section{References}

1. Davis, T.S.; Rhoades, P.R.; Mann, A.J.; Griswold, T. Bark beetle outbreak enhances biodiversity and foraging habitat of native bees in alpine landscapes of the southern Rocky Mountains. Sci. Rep. 2020, 10, 16400. [CrossRef]

2. $\quad$ Edburg, S.L.; Hicke, J.A.; Brooks, P.D.; Pendall, E.G.; Ewers, B.E.; Norton, U.; Gochis, D.; Gutmann, E.D.; Meddens, A.J. Cascading impacts of bark beetle-caused tree mortality on coupled biogeophysical and biogeochemical processes. Front. Ecol. Environ. 2012, 10, 416-424. [CrossRef]

3. Hlásny, T.; Zimová, S.; Merganičová, K.; Štěpánek, P.; Modlinger, R.; Turčáni, M. Devastating outbreak of bark beetles in the Czech Republic: Drivers, impacts, and management implications. For. Ecol. Manag. 2021, 490, 119075. [CrossRef]

4. Hlásny, T.; Krokene, P.; Liebhold, A.; Montagné-Huck, C.; Müller, J.; Qin, H.; Raffa, K.; Schelhaas, M.-J.; Seidl, R.; Svoboda, M.; et al. Living with Bark Beetles: Impacts, Outlook and Management Options. From Science to Policy 8; European Forest Institute: Joensuu, Finland, 2019; 50p, Available online: https://efi.int/sites/default/files/files/publication-bank/2019/efi_fstp_8_2019 .pdf (accessed on 10 July 2021).

5. CSO, Czech Statistical Office 2021 'Lesnictví-2020 (Forestry 2020)'. Available online: https:/ /www.czso.cz/csu/czso/lesnictvi2020 (accessed on 9 November 2021).

6. Löwe, R.; Sedmíková, M.; Natov, P.; Jankovský, M.; Hejcmanová, P.; Dvořák, J. Differences in Timber Volume Estimates Using Various Algorithms Available in the Control and Information Systems of Harvesters. Forests 2019, 10, 388. [CrossRef]

7. Hýsek, Š.; Löwe, R.; Turčáni, M. What Happens to Wood after a Tree Is Attacked by a Bark Beetle? Forests 2021, $12,1163$. [CrossRef]

8. Jelonek, T.; Klimek, K.; Kopaczyk, J.; Wieruszewski, M.; Arasimowicz-Jelonek, M.; Tomczak, A.; Grzywiński, W. Influence of the Tree Decay Duration on Mechanical Stability of Norway Spruce Wood (Picea abies (L.) Karst.). Forests 2020, 11, 980. [CrossRef] 
9. Kržišnik, D.; Lesar, B.; Thaler, N.; Humar, M. Performance of bark beetle damaged Norway spruce wood against water and fungal decay. BioResources 2018, 13, 3473-3486. [CrossRef]

10. Little, N.S.; McConnell, T.E.; Irby, N.E.; Shi, S.Q.; Riggins, J.J. Surface free energy of blue-stained southern pine sapwood from bark beetle-attacked trees. Wood Fiber Sci. 2013, 45, 206-214.

11. Konôpková, A.; Vedernikov, K.E.; Zagrebin, E.A.; Islamova, N.A.; Grigoriev, R.A.; Húdoková, H.; Petek, A.; Kmet', J.; Petrík, P.; Pashkova, A.S.; et al. Impact of the European bark beetle Ips typographus on biochemical and growth properties of wood and needles in Siberian spruce Picea obovate. Lesn. Cas. 2020, 66, 243-254.

12. Furniss, M.M.; Solheim, H.; Christiansen, E. Transmission of Blue-Stain Fungi by Ips typographus (Coleoptera: Scolytidae) in Norway Spruce. Ann. Entomol. Soc. Am. 1990, 83, 712-716. [CrossRef]

13. ČSN 49 0110. Dřevo. Mez pevnosti v tlaku ve směru vláken; Úřad pro Technickou Normalizaci, Metrologii a Státní Zkušebnictví: Praha, Czech Republic, 1979; Volume 8, p. 490110.

14. ČSN 49 0113. Zkoušky Vlastností Rostlého Dřeva. Metoda Zjišt'ování Pevnosti v tahu Podél Vláken; Úřad pro Technickou Normalizaci, Metrologii a Státní Zkušebnictví: Praha, Czech Republic, 1991; Volume 8, p. 490113.

15. Lindgren, O. Medical CT-Scanners for Non-Destructive Wood Density and Moisture Content Measurements. Doctoral Thesis, Luleå University, Skelleftea, Sweden, 1992; p. 92.

16. Zhou, L.; Chen, Z.; Olsson, L.; Grahn, T.; Karlsson, B.; Wu, H.X.; Lundqvist, S.O.; García-Gil, M.R. Effect of number of annual rings and tree ages on genomic predictive ability for solid wood properties of Norway spruce. BMC Genom. 2020, 21, 323. [CrossRef]

17. Roszyk, E.; Kwiatkowski, T.; Moliński, W. Mechanical parameters of pine wood in individual annual rings under tensile stress along the grains in dry and wet state. Wood Res. 2013, 58, 571-580, print ISSN 1336-4561.

18. Moliński, W.; Roszyk, E.; Fabisiak, E. Gradient of selected mechanical properties within individual annual rings in the resonance spruce wood (Picea abies L.). Wood Res. 2013, 58, 521-532, print ISSN 1336-4561.

19. Sonderegger, W.; Niemz, P. The influence of compression failure on the bending, impact bending and tensile strength of spruce wood and the evaluation of non-destructive methods for early detection. Holz Roh Werkst. 2004, 62, 335-342. [CrossRef]

20. Quinn, G.P.; Keough, M.J. Experimental Design and Data Analysis for Biologists; Cambridge University Press: New York, NY, USA, 2002; p. 537.

21. Babiak, M.; Gaff, M.; Sikora, A.; Hýsek, Š. Modulus of elasticity in three- and four-point bending of wood. Compos. Struct. 2018, 204, 454-465. [CrossRef]

22. Gindl, W.; Teischinger, A. Axial compression strength of Norway spruce related to structural variability and lignin content. Composites Part A. 2002, 33, 1623-1628. [CrossRef]

23. Schönfelder, O.; Zeidler, A.; Borůvka, V.; Bílek, L.V. Impact of silvicultural measures on the quality of scots pine wood part II. Effect of site. Wood Res. 2019, 64, 789-798, e-ISSN 2729-8906.

24. Witomsky, P.; Oleg, W.; Bonarski, J.T. Changes in strength of Scots pine wood (Pinus silvestris L.) decayed by brown rot (Coniophora puteana) and white rot (Trametes versicolor). Constr. Build. Mater. 2016, 102, 162-166. [CrossRef]

25. Reinprecht, L. Wood Deterioration, Protection and Maintenance, 1st ed.; Wiley-Blackwell: Hoboken, NJ, USA, 2016; p. 376. [CrossRef]

26. Oltean, L.; Teischinger, A.; Hamsmann, C. Influence of temperature on cracking and mechanical properties of wood during wood drying-A review. Bioresources 2007, 2, 789-811, ISSN 1930-2126.

27. Kloiber, M.; Tippner, J.; Hrivnák, J. Mechanical properties of wood examined by semi-destructive devices. Mater. Struct. 2014, 47, 199-212. [CrossRef]

28. Marais, B.N.; Brischke, C.; Militz, H.; Peters, J.H.; Reinhardt, L. Studies into Fungal Decay of Wood In Ground Contact-Part 1 : The Influence of Water-Holding Capacity, Moisture Content, and Temperature of Soil Substrates on Fungal Decay of Selected Timbers. Forests 2020, 11, 1284. [CrossRef]

29. Beagle, E.; Belmont, E. Technoeconomic assessment of beetle kill biomass co-firing in existing coal fired power plants in the Western United States. Energy Policy 2016, 97, 429-438. [CrossRef]

30. Roszyk, E.; Molinski, W.; Fabisiak, E.; Cunderlik, I. Radial variation of mechanical properties of spruce wood (Picea abies L.) in tension along the grain. Folia For. Polonica. Series B-Drzew. 2010, 41, 33-44, ISSN 0071-6685.

31. Machado, J.S.; Louzada, J.L.; Santos, A.J.A.; Nunes, L.; Anjos, O.; Rodrigues, J.; Simões, R.M.S.; Pereira, H. Variation of wood density and mechanical properties of blackwood (Acacia melanoxylon R. Br.). Mater. Des. 2014, 56, 975-980, ISSN 0261-3069. [CrossRef]

32. Zhang, S.Y. Effect of age on the variation, correlations and inheritance of selected wood characteristics in black spruce (Picea mariana). Wood Sci. Technol. 1988, 32, 197-204. [CrossRef] 